\title{
Clonal Variation in the Effects of Nitrogen Applied to Mother Plant on the Sprouting Behavior of Tubers of Arrowhead, Sagittaria trifolia L.
}

\author{
Shigeya Yamakawa*, Kinya Ide*, Hisao Kobayashi** and Kunikazu Ueki** \\ * Aburahi Laboratories, Shionogi and Co., Ltd., Koka-cho, Koka-gun, Shiga 520-34, Japan. \\ ** Faculty of Agriculture, Kyoto University, Kyoto 606, Japan.
}

\section{Introduction}

Edaphic ecotypes in nitrogen response have been shown in some species ${ }^{1,3,13,14)}$. A number of annual plants have been found to display variation in seed germination ${ }^{10,11,12,16,22)}$. Environmental differences, such as temperature, photoperiod and air humidity, during seed maturation reportedly affect germinating habits in some annual plants ${ }^{4,6,9,21)}$. Drainage of paddy field and the presence or absence of rice plants during growth of the mother plants of Sagittaria trifolia $\mathrm{L}$. influenced tuber dorman$\mathrm{cy}^{7)}$. Difference in nitrogen level applied to the mother plants also affected the tuber sprouting behavior of this species ${ }^{17}$.

S. trifolia has wide clonal variation in plant growth habits and propagule production ${ }^{19}$, and also in the patterns of these characteristics in response to nitrogen ${ }^{20}$.

The present study was conducted to clarify the effects of nitrogen applied to the mother plant of $S$. trifolia on the sprouting of tubers and clonal variation in response to nitrogen.

\section{Materials and Methods}

Nineteen clones from six locations in the southern part of Kyoto Prefecture and the growing method used in this study were the same as those described in a previous study ${ }^{20}$. Twenty ramets from one clone were divided into four experimental lots containing different amounts of nitrogen fertilizer. Four levels of nitrogen were obtained by varying the amount of sodium-nitrate mixed in $860 \mathrm{ml}$ soil : $0 \mathrm{mg}(0 \mathrm{~N}), 68.8 \mathrm{mg}(8 \mathrm{~N}), 137.6 \mathrm{mg}(16 \mathrm{~N})$ and $275.2 \mathrm{mg}(32 \mathrm{~N})$.

Fifteen to thirty-five tubers in each experimental lot of the 19 clones were randomly selected after the ramets were dug up at the beginning of December, 1981, when their aerial parts had withered completely. These tubers were stored in a wet condition at $5^{\circ} \mathrm{C}$ for about 70 days. Their fresh weights were measured, and then the tubers were placed in individual cells $(1.7 \times 1.7 \times 2.7 \mathrm{~cm})$ on February 19, 1982 . All cells were placed in a single tub and the water depth was kept at about $3 \mathrm{~cm}$ until the end of the cultivation. This tub was placed in a greenhouse at Aburahi Laboratories; water temperature was $16-27^{\circ} \mathrm{C}$ at the beginning of the experiment and increased progressively to $25-38^{\circ} \mathrm{C}$ at the beginning of August.

Tubers which had just sprouted were dried at $80^{\circ} \mathrm{C}$ in an air-drafted oven and weighed. Sprouting of the tubers was observed for about 250 days.

\section{Results}

Nitrogen applied to the mother plant influenced the number of days to tuber sprouting. Among the four nitrogen levels used, $32 \mathrm{~N}$ caused the fastest sprouting, as shown in Fig. 1. The relationship in days to sprouting between $8 \mathrm{~N}$ and the other three nitrogen levels, 0,16 and $32 \mathrm{~N}$, are represented by the 


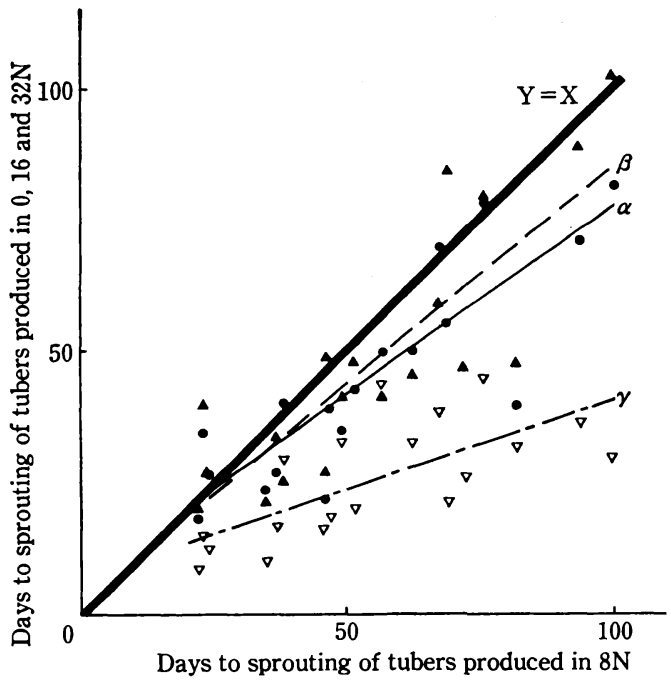

Fig. 1. Relationship in the days to sprouting of tubers produced in $8 \mathrm{~N}$ and the other three nitrogen levels, $0(\boldsymbol{O}), 16(\boldsymbol{\Delta})$ and $32 \mathrm{~N}(\nabla)$.

Each mark shows the mean value of tubers produced by a clone.

$\alpha: \mathrm{Y}=5.597+0.720 \mathrm{X}, \mathrm{r}=0.882(\mathrm{n}=19, \mathrm{p}<$ $0.01)$ : the relationship between $8 \mathrm{~N}$ and $0 \mathrm{~N}$.

$\beta: Y=2.383+0.828 X, r=0.866(n=19, p<$ $0.01)$ : the relationship between $8 \mathrm{~N}$ and $16 \mathrm{~N}$.

$\gamma: \mathrm{Y}=7.051+0.330 \mathrm{X}, \mathrm{r}=0.737(\mathrm{n}=19, \mathrm{p}<$ $0.01)$ : the relationship between $8 \mathrm{~N}$ and $32 \mathrm{~N}$.

estimated regression lines $\alpha, \beta$ and $\gamma$, respectively. These regression lines were significantly different from the theoretical line $\mathrm{Y}=\mathrm{X}$. Line $\gamma$ was significantly different from the two other lines, $\alpha$ and $\beta$, which were not significantly different from each other.

According to the nitrogen response in tuber sprouting, the 19 clones were divided into groups A, B, C and D of nine, two, five and three clones, respectively (Fig. 2) : A : those in which the days to sprouting of tubers grown only at $32 \mathrm{~N}$ was significantly shorter than that at $8 \mathrm{~N}$; $\mathrm{B}$ : those in which the days to sprouting of tubers grown at $0 \mathrm{~N}$ and $32 \mathrm{~N}$ was significantly shorter than that at $8 \mathrm{~N} ; \mathrm{C}$ : those in which the days to sprouting of tubers grown at $8 \mathrm{~N}$ was the longest ; $\mathrm{D}$ : the remain- ing three clones, Nos. 3, 6 and 13.

The days to sprouting of tubers of No. 3 grown at 8 and $32 \mathrm{~N}$ were shorter than those at 0 and $16 \mathrm{~N}$. Clone No. 3 belonging to group $\mathrm{D}$ showed a lower value at $8 \mathrm{~N}$ than that at 0 and $16 \mathrm{~N}$, but the value at $8 \mathrm{~N}$ in this experiment was especially shorter than that at $8 \mathrm{~N}$ in other years. The days to sprouting of No. 6 grown at both 16 and $32 \mathrm{~N}$ were significantly shorter than those at both 0 and $8 \mathrm{~N}$. The days to sprouting of No. 13 grown at $16 \mathrm{~N}$ were the shortest among the four nitrogen levels.

The effects of nitrogen applied to the mother plants on the relative frequency of days to tuber sprouting in clone Nos. 1, 6, 12,15 and 18, which exhibited different representative patterns, are shown in Fig. 3. Clone Nos. 1 and 12 belonged to group A, and Nos. 15, 18 and 6 to groups $\mathrm{B}, \mathrm{C}$ and $\mathrm{D}$, respectively. Tubers of No. 1 grown at $8 \mathrm{~N}$ sprouted gradually over a long period, and sprouting behavior did not differ from that at 0 and $16 \mathrm{~N}$; however, the tubers of $32 \mathrm{~N}$ sprouted quickly and simultaneously. The sprouting pattern of No. 12 grown at $8 \mathrm{~N}$ did not resemble that at 0 and $16 \mathrm{~N}$ levels, decreasing at $32 \mathrm{~N}$. The tubers of No. 12 at $8 \mathrm{~N}$ sprouted simultaneously and more quickly than that of No. 1 at the same nitrogen level, but the changing pattern of sprouting behavior of this clone among the four nitrogen levels most resembled that of No. 1. The period to sprouting of No. 15 at $0 \mathrm{~N}$ was shorter than those at 8 and $16 \mathrm{~N}$, and that at $32 \mathrm{~N}$ was the shortest and was simultaneous among the four nitrogen levels. The tubers of No. 18 at $8 \mathrm{~N}$ sprouted gradually over a long period, while tubers of the other three nitrogen levels sprouted simultaneously and more quickly. The tubers of clone No. 6 at 16 and $32 \mathrm{~N}$ sprouted more quickly than those at 0 and $8 \mathrm{~N}$.

The relationship between the tuber characteristics of percent dry matter and dry weight and the days to tuber sprouting displayed marked variation as shown in Fig. 4. The days to sprouting of tubers of No. 1 increased 


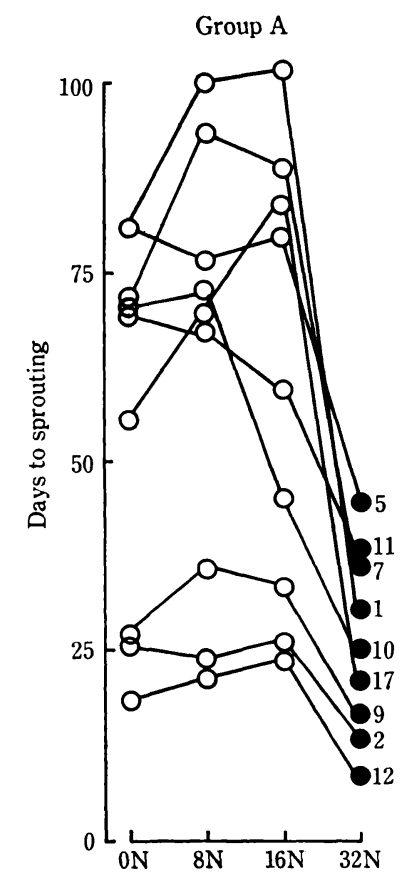

Group B

Group C

Group D
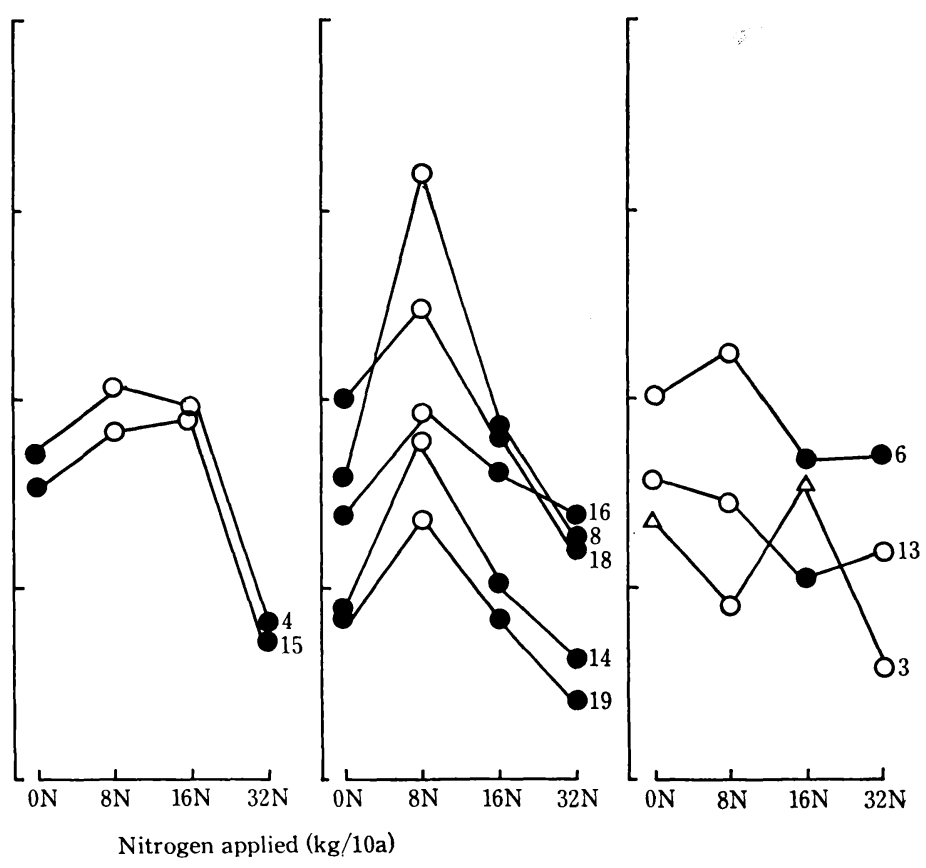

Fig. 2. Clonal variation of nitrogen response in tuber sprouting.

: no difference to the value of $8 \mathrm{~N}$ at $5 \%$ level.

: shorter than the value of $8 \mathrm{~N}$ at $5 \%$ level.

$\triangle$ : longer than the value of $8 \mathrm{~N}$ at $5 \%$ level.

Figure at the right of the symbol indicates clone Number.

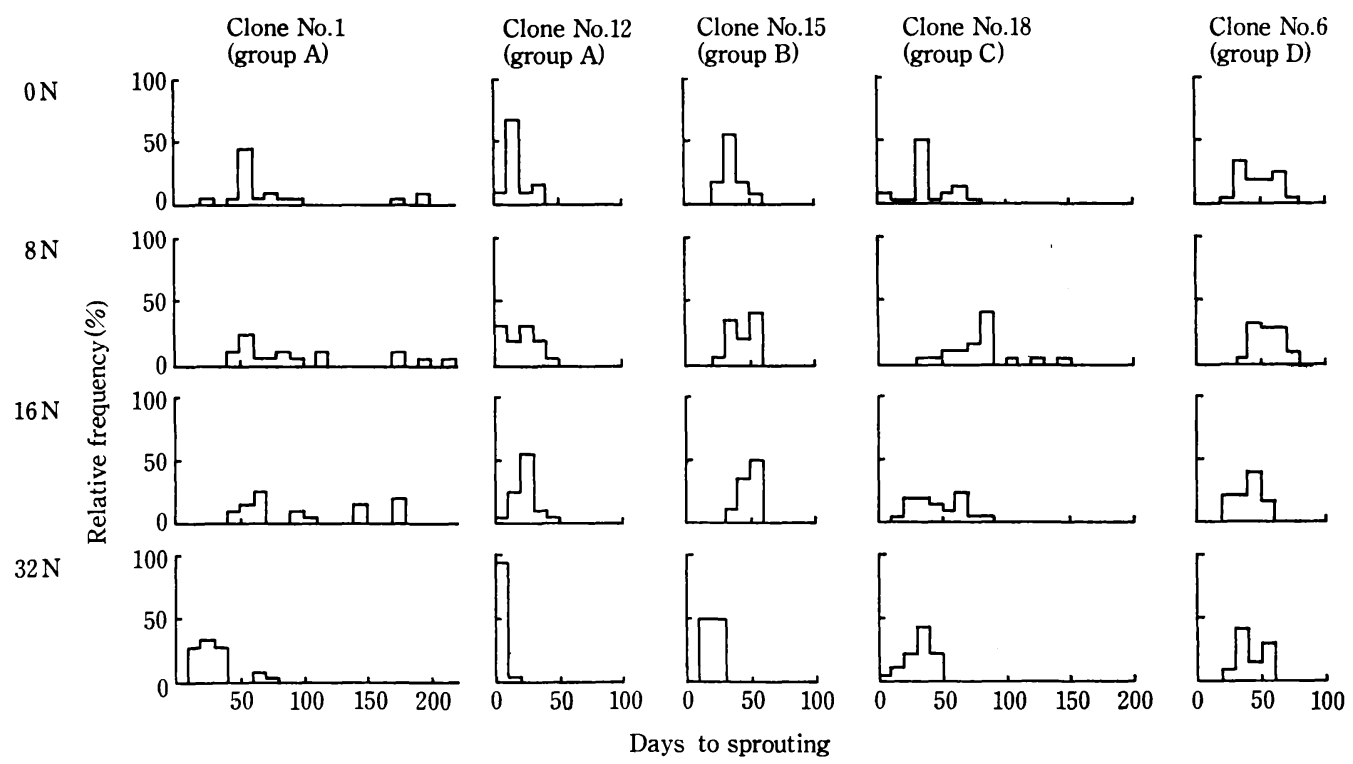

Fig. 3. Clonal variation of nitrogen response in the relative frequency of days to sprouting of tubers. The representative clones of the sprouting pattern are shown, with the group in parenthesis. 

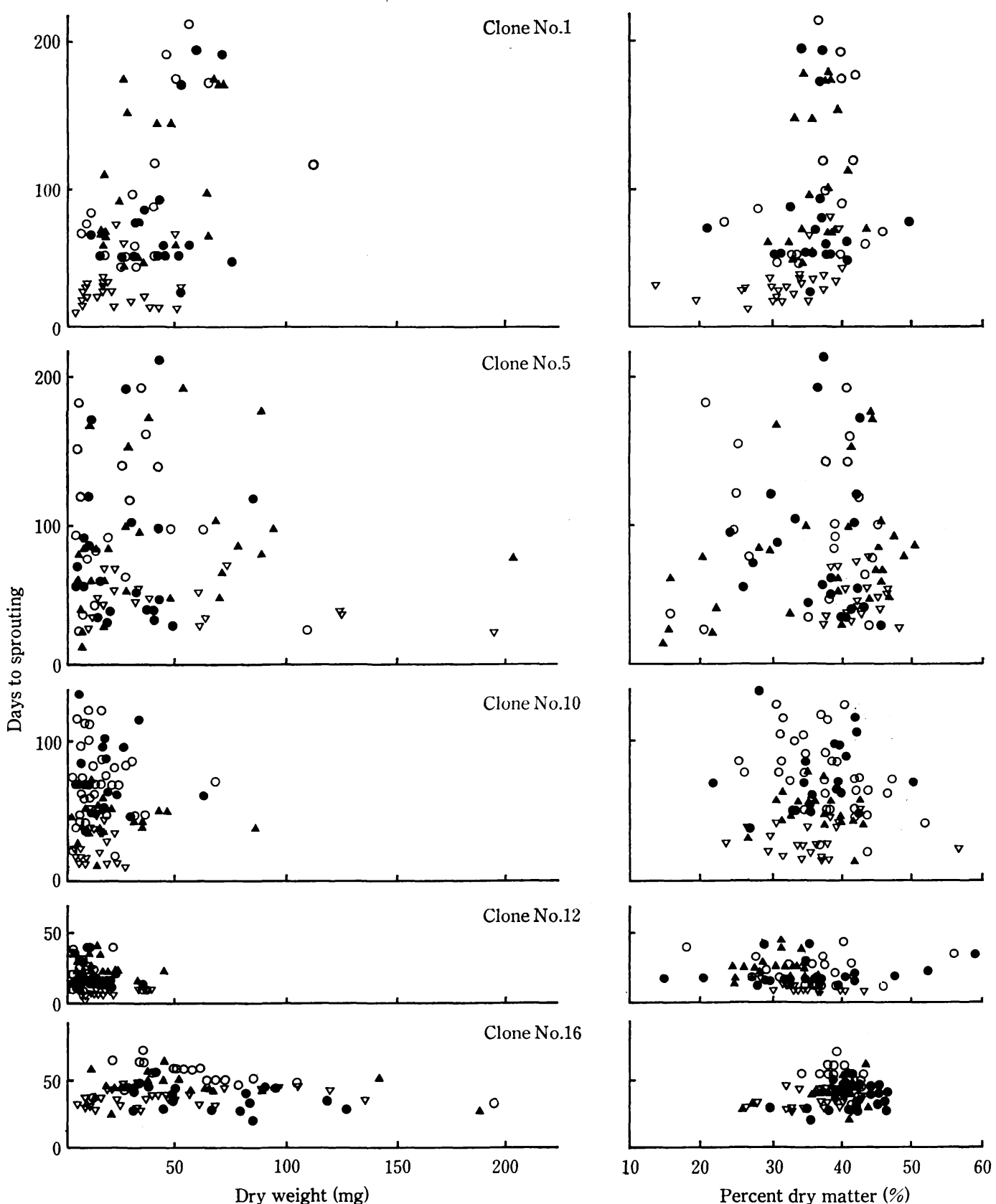

Fig. 4. Clonal variation in effect of nitrogen application on the relationship between dry weight or percent dry matter and days to sprouting of tubers.

$: 0 \mathrm{~N}, \bigcirc: 8 \mathrm{~N}, \triangle: 16 \mathrm{~N}, \nabla: 32 \mathrm{~N}$. 
with the increase of the percent dry matter and dry weight of tubers, and this tendency did not correlate to the amount of nitrogen applied. This relationship was not recognized in the remaining four clones, Nos. 5, 10, 12 and 16.

\section{Discussion}

Differences in nitrogen applied to mother plants of Sagittaria trifolia influenced plant growth, the amount of propagule production, percent dry matter of tubers and the relationship between tuber size and the number produced ${ }^{17,18)}$. Wide clonal variation of the nitrogen response of these characteristics was also observed $^{20)}$.

Iтон and MiyahaRA ${ }^{7)}$ reported that differences in the environment of the mother plant, such as drainage of the paddy field and the presence or absence of rice plants, affected tuber dormancy of this species. The number of days to tuber sprouting increased as the amount of nitrogen applied to the mother plant increased $^{17)}$.

In this study, the difference in the amount of nitrogen level applied to the mother plants influenced tuber sprouting behavior : tubers at $32 \mathrm{~N}$ sprouted more quickly than those at 0,8 and $16 \mathrm{~N}$ (Figs. 1, 2 and 3). With all 19 clones, except No. 3, the days to tuber sprouting increased from $0 \mathrm{~N}$ to $8 \mathrm{~N}$ but decreased from $8 \mathrm{~N}$ to $32 \mathrm{~N}$. Consequently, the nitrogen level applied to mother plant strongly affects tuber sprouting behavior. As numerous environmental factors affect seed or tuber dormancy in plants $4,6,9,15,21)$, many factors other than nitrogen, paddy drainage and the presence or absence of rice plants probably also affect tuber sprouting behavior of this species. Differences in the amount of nitrogen applied hardly altered individual tuber weight and percent dry matter, except for the tubers produced by poorly growing individuals ${ }^{20)}$. Changes of the tuber sprouting pattern among nitrogen levels probably is not due to the differences in the degree of tuber maturation but to other factors.

Kоваунанi et $a l .{ }^{8)}$ found that the period to tuber sprouting of 18 among 40 clones of Eleocharis kuroguwai were related positively or negatively to the fresh or dry weight and the percentage dry matter or tuber shape, although the remaining 20 clones did not show such a tendency. S. trifolia, like E. kuroguwai, shows wide clonal variation in the relationship between the days to sprouting and percent dry matter or dry weight. The period to sprouting of one clone, No. 1, of the five clones in Fig. 4, significantly increased with the increase in percent dry matter and also the dry weight of tubers. However, such relationship was not found in the remaining four clones, Nos. 5, 10, 12 and 16.

As discussed above, nitrogen applied to the mother plant strongly affected the tuber sprouting habit of all 19 clones. S. trifolia varies widely in this characteristic ; moreover, both the pattern and degree of nitrogen response of tuber sprouting differed among the clones. Eleocharis kuroguwai was divided into three groups on the basis of its tuber sprouting patterns, which were related to the adaptive characteristic of individual habitats ${ }^{8}$. CAVERS and HARPER ${ }^{2)}$ identified factors which affect seed germination polymorphisms: some of which could be ascribed to seed ripeness or its position on the plant, but most of the variation occurred among plants within a small habitat sample; the variation was greater among plants than among habitats. HARPER ${ }^{5)}$ concluded that this phenomenon is a general tendency in plants. However, in the present study, the relationship between sprouting behavior and the habitat characteristic was not clarified because of the small number of clones used and the locations sampled. This species must grow under many kinds of nitrogen environments and compete with other weeds together with rice plants. This species displays a broad variation of nitrogen response in its plant growth and propagule production in 
relation to its location ${ }^{20)}$. Thus, the nitrogen response of the tuber sprouting pattern must differ among locations.

\section{Summary}

Clonal variation in the influence of different levels of nitrogen applied $(0,8,16$ and $32 \mathrm{~kg} /$ 10a) to mother plants on tuber sprouting behavior was investigated for 19 clones of Sagittaria trifolia L., which were collected from six locations in the southern part of Kyoto prefecture.

Differences in the nitrogen levels affected the days to tuber sprouting; the period to sprouting at $32 \mathrm{~N}$ were shorter than those at the other three nitrogen levels. There was wide clonal variation not only in the days to sprouting at each nitrogen level, but also in the nitrogen response of this characteristic. Based on the nitrogen response of the days to sprouting, the 19 clones were divided into four groups, A, B, C and D, of nine, two, five and three clones, respectively : $\mathrm{A}$ : those in which the days to sprouting only at $32 \mathrm{~N}$ was significantly shorter than at $8 \mathrm{~N} ; \mathrm{B}$ : those in which the days to sprouting at 0 and $32 \mathrm{~N}$ were significantly shoter than at $8 \mathrm{~N}$; $\mathrm{C}$ : those in which the days to sprouting at 0,16 and $32 \mathrm{~N}$ were significantly shorter than at $8 \mathrm{~N} ; \mathrm{D}$ : the remaining clones.

The effects of the nitrogen levels applied to the mother plants on the relative frequency of the days to tuber sprouting also differed among clones. The sprouting pattern of group $\mathrm{A}$ was not so different among 0,8 and $16 \mathrm{~N}$, while the tubers of $32 \mathrm{~N}$ sprouted more quickly and synchronously. The tubers of group $\mathrm{B}$ of $0 \mathrm{~N}$ sprouted more quickly than those of 8 and $16 \mathrm{~N}$, and those of $32 \mathrm{~N}$ sprouted the most quickly and simultaneously among four nitrogen levels. The tubers of group $\mathrm{C}$ at $8 \mathrm{~N}$ sprouted gradually over a long period, while tubers at the other three nitrogen levels sprouted more quickly and simultaneously.

The relationship between percent dry mat- ter or dry weight of tubers and the period to sprouting displayed remarkable variations. The days to sprouting of tubers of clone No. 1 increased with the increase of percent dry matter or dry weight in comparison with the other clones, and this tendency differed with the nitrogen dosage. This relationship was not recognized in clone Nos. 5, 10, 12 and 16.

\section{References}

1) Antonovics, J., J. Lovett and A.D. Bradshaw : The evolution of adaptation to nutritional factors in populations of herbage plants. In "Isotopes in Plant Nutrition and Physiology"-Inter. Atomic Energy Agency, Vienna, pp. 549-567 (1967).

2) CAvers, P.B. and J. L. HARPER (1966) : Germination polymorphism in Rumex crispus and Rumex obtusifolius. J. Ecol. 54, 367-382.

3) Crossley, G.K.: Variation in the nutritional requirements of natural and bred strains of some British pasture grasses. $\mathrm{Ph}$. D. thesis, Univ. Wales, (1963). Cited in Kawano, S.: Evolutionary Biology in Plants. II. Speciation and Adaptation. Sanseido Co., Ltd., Tokyo, p. 407 (1974) (in Japanese).

4) Evenari, M., D. Koller and Y. Gutterman (1966) : Effects of environment of the mother plant on germination by control of seed-coat permeability to water in Ononis sicula Guss. Aust. J. Biol. Sci. 19, 1007-1016.

5) Harper, J. L. : Population Biology of Plants. Academic Press, London, pp. 72-74 (1977).

6) IKehashi, H. (1972) : Induction and test of dormancy of rice seeds by temperature condition during maturation. Japan. J. Breed. 22, 209-216 (in Japanese with English summary).

7) Iтон, K. and M. Miyahara (1984): Time of breaking of dormancy of Sagittaria trifolia L. and a few factors relating it. Weed Res. Japan. 24 (suppl.), 93-94 (in Japanese).

8) Kobayashi, H., T. Tominaga and K. UeKI (1986) : Clonal variation in the sprouting pattern of the tubers in Eleocharis kuroguwai, a cyperaceous weed, with special reference to its perennation strategy. Plant Species Biology 1, 127-134.

9) Koller, D. (1962) : Preconditioning of germination in lettuce at time of fruit ripening. Amer. J. Bot. 49, 841-844. 
10) Matsumura, M. (1967): Genecological studies on the foxtail grass, Alopecurus aequalis, in Japan. Mem. Fac. Agr. Gifu Univ. 25, 129-208 (in Japanese with English summary).

11) Matsumura, M., N. Tanaka and I. Hirayoshi (1960) : Physiological and ecological studies on germination of Digitaria seeds. (1) Differences in response to germinating conditions and dormancy among individual plants. Mem. Fac. Agr. Gifu Univ. 12, 89-96 (in Japanese with English summary).

12) New, J. K. (1958) : A population study of Sperugula arvensis. I. Two clines and their significance. Ann. Bot. 22, 457-477.

13) Ramakrishman, P.S. and U. Gupta (1973) : Nitrogen, phosphorous and potassium nutrition of the edaphic ecotypes in Cynodon dactylon (L.) Pers. Ann. Bot. 37, 885-894.

14) Ramakrishman, P.S. and R. Kumar (1976) : Adaptive response of an alkaline soil population of Cynodon dactylon (L.) Pers. to NPK nutrition. J. Ecol. 64, 187-193.

15) RAO, S.N. and S.H. Wittwer (1955): Further investigation on the use of maleic hydrazide as a sprout inhibitor for potatoes. Amer. Potato J. 32, 51-59. Cited in OKazawa, Y. (1975) : Control of growth and development in potato plants. Proc. Crop. Sci. Soc. Japan 44, 123-139 (in Japanese).

16) Thurston, J. M. : Dormancy in weed seeds. In "The Biology of Weeds" ed. by HarPer J.L., Blackwell Scientific Publication, Oxford, pp. 69$82(1960)$.
17) Yamakawa, S., H. Kobayashi and K. UeKI (1978): Effects of nitrogen application levels and photoperiodic conditions on the propagule production of Sagittaria trifolia L. Weed Res. Japan. 23 (suppl.), 174-175 (in Japanese).

18) Yamakawa, S., H. Kobayashi and K. Ueki (1979): Effects of nitrogen application on growth and propagule production of arrowhead, Sagittaria trifolia L. Weed Res. Japan. 24, 81-85 (in Japanese with English summary).

19) YamaKawa, S., K. Ide, H. Kobayashi and K. UeKI (1983): Intraspecific variation of Sagittaria trifolia L. Growth behavior in clones collected in Kinki district. Weed Res. Japan. 28 (suppl.), 13-14 (in Japanese).

20) Yamakawa, S., K. Ide, H. Kobayashi and K. UeKI (1986): Clonal variation in the effects of nitrogen application on growth and propagule production of arrowhead, Sagittria trifolia L. Weed Res. Japan. 31, 41-50.

21) Yasue, T. and M. Huruta (1971): The influence of environmental conditions during the ripening of seed on dormancy and germination in rice seed. Mem. Fac. Agr. Gifu Univ. 31, 31-39 (in Japanese with English summary).

22) Williams, J. Y. and J.L. HARPER (1965): Seed polymorphism and germination. I. The infiuence of nitrates and low temperatures on the germination of Chenopodium album. Weed Res. 5, 141150 .

(Received November 28, 1986)

\section{親植物に対する窒素施用量の差異がオモダカ塊茎の \\ 萌芽に及ぼす影響のクローン間差異について \\ 山河重弥* - 井手欽也 ${ }^{*}$ - 小林央往 ${ }^{* *}$ - 植木邦和** \\ *塩野義製薬(株)油日ラボラトリーズ, **京都大学農学部}

摘要

本研究は, 京都府南部の 6 地域の水田から採取した 19 クローンのオモダカを $0,8,16$ および $32 \mathrm{~kg} / 10 \mathrm{a}$ (それ ぞれ $0 \mathrm{~N}, 8 \mathrm{~N}, 16 \mathrm{~N}$ ，および $32 \mathrm{~N}$ 区と略記する）の 4 窒素施用条件下で栽培し，得られた塊茎の萌芽性をクローン 別に調査したものである。1981年12月上旬に掘り上げた塊茎を約 70 日間 $5^{\circ} \mathrm{C}$ 湿潤状態で保存し，1982年 2 月 19 日に 1 クローンの 1 窒素施用区につき 15 から30塊茎をガラス温室内の小さく区画されたバット $(1.7 \times 1.7 \times 2.7 \mathrm{~cm})$ に個体 
別に置床し, 実験終了まで $3 \mathrm{~cm}$ の水深とした。萌芽までの日数は各塊茎毎に調査し, 萌芽後塊茎は直ちに $80^{\circ} \mathrm{C} て ゙$ 乾 燥させ, 重量を湘定した。

親植物に対する窒素施用量の差異は，いずれのクローン由来の塊茎の萌芽日数にも大きな影響を及ぼした。特に， $32 \mathrm{~N}$ 区では $8 \mathrm{~N}$ 区に比べて著しく萌芽日数が短縮した。窒素に対する反応に基づいて19クローンは次の 4 群に分け られた。A 群 : $32 \mathrm{~N}$ 区の塊茎のみが $8 \mathrm{~N}$ 区の塊茎より早く萌芽した。B 群 : $0 \mathrm{~N}$ 区および $32 \mathrm{~N}$ 区の塊茎萌芽日数が $8 \mathrm{~N}$ 区より短くなった。C 群 $: 0 \mathrm{~N}$ 区，16 N 区和よび $32 \mathrm{~N}$ 区の塊茎の萌芽が $8 \mathrm{~N}$ 区より早くなった。D群：その他。 また, 親植物に対する窒素施用量が塊茎の萠芽日数の頻度分布に及ぼす影響にも大きなクローン間差異が認められ た。 A 群では $32 \mathrm{~N}$ 区の塊茎萌芽が他の 3 つの区に比べ早くかつ萌芽まで日数の変異が小さかった。 B 群の $0 \mathrm{~N}$ 区の 塊茎萌芽は $8 \mathrm{~N}$ 区括よび $16 \mathrm{~N}$ 区に比べ早く，また， $32 \mathrm{~N}$ 区の塊茎萌芽が 4 区中最も早くかつ萌芽まで日数の変異が 小さかった。C 群の8 $\mathrm{N}$ 区に和ける塊茎萌芽は長期間にわたっていたが，他の 3 区では $8 \mathrm{~N}$ 区に比べより早くかつ变 異が小さかった。

塊茎の乾物重や乾物率と萌芽日数との関係もクローン間で差異があり，この関係に叔ける窒素反応もクローン間で 異なっていた。クローンNo. 1 の塊茎萌芽日数は塊茎の乾物重拉よび乾物率の增加にともない増加した。そして, こ の関係は窒素施用量の差異により影響を受けた。このような関係はクローンNo. 5, 10, 12 および 16 では認められ なかった。 